\title{
Conflict Management Styles (Dominating and Compromising) of Academic Administration and Its Impact on Faculty Job Satisfaction and Turnover Intention
}

\author{
Noor Un Nissa* \\ Institute of Commerce, University of Sindh, \\ Jamshoro, Sindh \\ Muhammad Nawaz \\ Institute of Commerce, University of Sindh, \\ Jamshoro, Sindh
}

\author{
Ashique Ali Jhatial \\ Institute of Commerce, University of Sindh, \\ Jamshoro, Sindh \\ Jamshed Adil Halepota \\ Institute of Commerce, University of Sindh, \\ Jamshoro, Sindh
}

\begin{abstract}
Generally, conflict is considered normal in personnel interaction at the workplace. Normally, it is conceptualized as destructive, but how conflict is dealt with determines whether it is productive or counterproductive. Employee negative and positive outcomes depend upon the efficient handling of conflict by conflict management at the workplace. This study investigates the role of conflict management styles and their impact on employee work-related attitudes, e.g., job satisfaction and turnover intention. This study has been carried out in public universities of Sindh Province, including the University of Sindh, Mehran University of Information and Technology and Liaquat Medical College. 150 questionnaires were used to derived results. The questionnaires were distributed to faculty members of universities. Results demonstrate that if supervisors at the workplace exercise dominating management style, employees feel psychological withdrawal from work, e.g., Turnover Intentions; however, employees are more satisfied with supervisors who demonstrate a compromising conflict management style. This study contributes by providing comprehensive detail on how conflict management styles affect employee work attitudes and an in-depth study on how supervisors/bosses make strategies that positively impact employee work attitudes.
\end{abstract}

Keywords: Conflict management, dominating, compromising, turnover intention, job satisfaction

Received: 9 August 2018; Accepted: 12 September 2018; Published: 3 October 2018

\section{INTRODUCTION}

As it is said "While some types of conflict can be detrimental to a team's success, other forms create a more open, more creative, and ultimately more productive team. The key is knowing how to steer the team toward constructive conflict" (Adams, 1965; Liu \& Dong, 2016; Ozyurek \& Uluturk, 2016).

"It is a process in which one party perceives that its interests are being opposed or negatively affected by another party" (Bhalerao, 2016; Thanasripanitchai, 2017; Wall \& Callister, 1995). When we hear word conflict, we definitely think about "issue". We never consider conflict as Pleasant or Positive. But according to Tjosvold (2008) "To work in an organization is to be in conflict. To take advantage of joint work requires conflict management". Truly it can be innovative, creative and positive for productivity and growth of organization, if management handle it efficiently.

${ }^{*}$ Correspondence concerning this article should be addressed to Noor Un Nissa, Institute of Commerce, University of Sindh, Jamshoro, Sindh. E-mail: noorbaloch60@gmail.com

(c) 2018 The Author(s). Published by KKG Publications. This is an Open Access article distributed under a Creative Commons Attribution-NonCommercial-NoDerivatives 4.0 International License. 
So being an efficient manager it is his/her duty to manage positive and negative outcomes of conflict by handling it properly. It is task of conflict management to indicate and eradicate the negative conflicts from workplace.

Un efficient handling of conflict can lower the satisfaction of employee regarding their work in organization. According (Alimba, 2008; Mahdieh, 2015; Pahayahay, Asejo, Pangan, Dasig Jr., \& Panganiban Jr., 2017) "conflict is considered as the most volatile factor that can thwart the productivity of individual workers". It was proposed in this study that employees who perceived poorly managed conflicts at work place those highly intent to leave organization and less satisfied with their job. Therefore, employee's satisfaction and psychological involvement in job is extremely depend on conflict handling style of management.

Mainly this study has been carried out to investigate some specific conflict management styles including dominating and compromising and its impact on two employee work related outcomes e.g., job satisfaction and turnover intension.

\section{LITERATURE REVIEW}

As it is said by Carpenter and Kennedy (2001) Existence of Conflict in organization is "inevitable", even it is explored by De and Van (2001) that somehow conflict is anticipated and sometimes chosen by will. According to Dennis (1998) outcomes of conflict can determine that how it is handled. De and Van (2001) stressed that, "excessive conflict can induce stress, frustration, dissatisfaction, high turnover, absenteeism, and poor performance among employees."

\section{Conflict Management Styles}

Blake and Mouton (1964) first introduced the model of conflict management styles. In which there were five styles of handling including problem-solving, smoothing, forcing, withdrawal, and sharing. This model was then redesign by Thomas (1976). Later a model by Rahim and Bonoma (1979) have been proposed which was widely used and strongly empirically tested. They introduced five styles including obliging, avoiding, dominating, integrating and compromising, having two dimensions (concern for self and concern for others).

Concern for Self

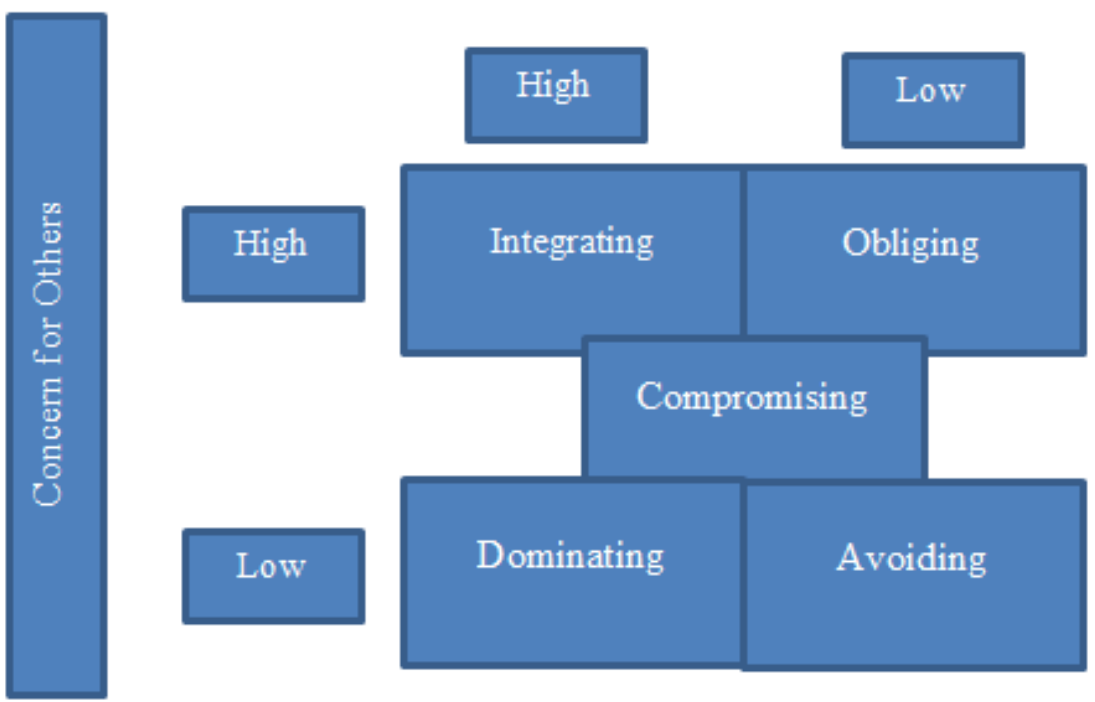

Figure 1 Conceptual Diagram

The five conflict styles develop from various combinations of these two dimensions are: "(1) integrating-high concern for both self and others, (2) dominating - high concern for self and low concern for others, (3) obliginglow concern for self and high concern for others, (4) avoiding-low concern for both self and others, and (5) compromising - moderate levels of concern for both self and others".

Nevertheless, this was proposed to test only two conflict handling styles including Dominating and Compromising with two work related outcomes. The major aim of this study is to identify that whether the employees intends to leave or stay in the organization who supervised by those supervisors/bosses who tends to exercise dominating style or not. And also, are employees are satisfied or dissatisfied from there supervisors/bosses who use compromising style of 
handling conflict. So, we will discuss these variables in brief.

\section{Dominating}

As G. Ferris, Russ, and Fandt (1989) that some conflict resolution styles (e.g., integrating, compromising, and obliging styles) are associated with positive outcomes like employee satisfaction with supervisor. Whereas some are (e.g., dominating and avoiding styles) strongly associated with negative outcomes. Likewise, different studies including (Kahn, Wolfe, Quinn, Snoek, \& Rosenthal, 1964; Likert, 1967) have also revealed that the employees of that organizations whose management excessively adopt dominating and avoiding management styles, suffer from negative work-related outcomes. On other hand management with integrating, obliging and compromising styles have positive impact on employee work related outcomes. Compromising conflict management style is negatively related with Turnover Intentions

\section{Compromising}

In the same way according to (Alper, Tjosvold, \& Law, 2000; Van, Euwema, \& Huismans, 1995) compromising is most effective way to resolve conflict and make quality relationship among employees. As said by Alper et al. (2000) compromising is consider as "middle ground" solution. Means in compromising management openly listen and understand issues and problems of both parties are resolve conflict accordingly to benefit both parties. So, its is said by Van et al. (1995) that it is compromising is most favourable conflict resolution style as it resolves issues of both parties and create a sound relationship among employees at workplace. On contra a study by (De \& Van, 2001) concluded that compromising to not much effective as it was expected. Also, it is said by Thomas (1976) compromising style is useful where there are mutual interest of both parties and might have opposite effects on other conditions. Compromising conflict management style is positively related with Job Satisfaction

\section{Turnover Intentions}

Turnover intention was conceived to be a conscious and deliberate wilfulness to leave the organization (Tett \& Meyer, 1993). Employees intend to leave organization if they are not satisfying with their job and organization as concluded by (Jehn \& Chatman, 2000). It was also concluded that "conflict is a phenomenon can manifest in diverse ways such as strike, absenteeism sabotage, labour turnover, pilfering, restriction of output, lockout and a host of others" (Choi, 2013). Likewise it was suggested by (Wall \& Callister, 1995) that conflict negatively effects work-related outcomes including turnover intentions. Dominating conflict management style is positively related with Turnover Intentions

\section{Job Satisfaction}

Satisfaction is defined by (Millikan, 1984; Papineau, 1987) as “fulfilment of one's wishes, desires, expectations or needs". In prior studies e.g., (Thomas, 1976) suggested that role of conflict management to manage conflict in this way to mitigate negative impacts and promote justice. Effectiveness, efficiency and job satisfaction. As it is said by Brown and Peterson (1993) the main objective of conflict management is to boost learning and positive outcomes of individuals, which are including efficiency or performance in organization. Likewise, it was concluded by (Judge, 1994) to measure the effectiveness of organizational conflict management we determine some basic work-related outcomes including job satisfaction and employee performance. Dominating conflict management style is negatively related with Job Satisfaction.

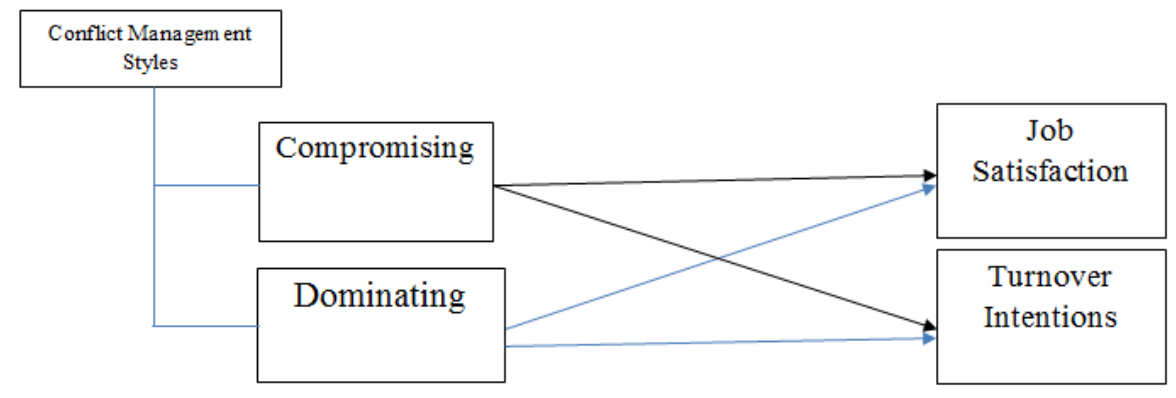




\section{RESEARCH METHODOLOGY}

\section{Statistical Tools}

For description statistics and to measure the reliability of scales the Spss has been used. To test the model of the study, SEM has been performed in smart pls.

\section{Sampling Design}

The sample for this study comprises of faculty member and administration of public sector universities.130 questionnaires were distributed to the faculty and administration from which 100 were usable for further analysis. random sampling method were used to collect data. Data was collected through survey questionnaires. 7-point Likert scale to assess results.

\section{Research Instruments}

Conflict management styles: Conflict management styles were measure by using the "ROCI-II (Rahim \& Bonoma, 1979)". This multi-item instrument contains 28 items. The "ROCI-II" was designed to measure 5 dimensions or styles of resolving conflict, 4 items for measuring compromising style sample items were "My boss tries to find a middle course to resolve an impasse" and "My boss negotiates with me so that a compromise can be reached" and 5 items for measuring dominating style sample items were "My boss uses his/her influence to get his/her ideas accepted" and "My boss uses his/her authority to make a decision in his/her favour".

Job satisfaction: 10 items were adopted from the study of Macdonald and Maclntyre (1997). Sample Items are e.g., "I receive appreciation for well-done job" and "I feel good about working at this university".

Turnover intentions: Three items were used to measure intent to turnover within organization, developed by Cammann, Fichman, Jenkins, and Klesh (1979). Sample Items are "1 often think of leaving the organization" and "If I may choose again, I will choose to work for the current organization".

\section{Data Analysis Techniques}

In order to determine the Reliability and factor analysis has been performed through SPSS. To test the model, Structural Equation Modelling (SEM) through statistical tool Partial Least Square (Smartpls) has been applied.

\section{RESEARCH RESULTS}

200 questionnaires were distributed, from the total of questionnaires 150 were usable for the final analysis. SPSS version 22.0 was used to analyze the data which included the demographic information categorized as gender, $62 \%$ were male and 38\% were female. In age segment, the highest proportion of respondents was in age of 20-29 years. However, the education level of the respondents was high. Nearly $41 \%$ of the respondents were enrolled in MPhil $/ \mathrm{PhD}$. The large numbers of respondents were permeant teaching faculty $83 \%$ and remaining are of visiting faculty. $46 \%$ of respondent having the work experience of between 10-20 years. 
Table 1 DEMOGRAPHICS

\begin{tabular}{llll}
\hline \multirow{2}{*}{ Demographics } & Categories & Frequency & Percentage \\
\hline Gender & Male & 62 & 62.0 \\
Marital Status & Female & 38 & 38.0 \\
Age & Married & 45 & 45.0 \\
& Single & 55 & 55.0 \\
& 20 to 29 & 61 & 61.0 \\
Education & 30 to 39 & 27 & 27.0 \\
& 40 to 49 & 4 & 4.0 \\
Experience & 50 above & 8 & 8.0 \\
& Bachelor's Degree & 19 & 19.0 \\
& Master's Degree & 40 & 40.0 \\
& MPhil/PhD & 41 & 41.0 \\
& Less 1 year & 24 & 24.0 \\
Occupation & 10-20 years & 46 & 46.0 \\
& 21-30 years & 24 & 24.0 \\
& 31-40 years & 1 & 1.0 \\
& 41-above & 5 & 5.0 \\
\hline
\end{tabular}

\section{Reliability Score}

This table shows the Cronbach's alpha reliability of each construct and all overall reliability of all constructs. Results indicates all constructs have good reliability score.

Table 2 RELIABILITY SCORE

\begin{tabular}{lll} 
Items & No. of Items & Reliability \\
\hline Compromising & 4 & .850 \\
Dominating & 5 & .770 \\
Job Satisfaction & 6 & .799 \\
Turnover Intention & 3 & .784 \\
Overall & 18 & .799 \\
\hline
\end{tabular}

\section{Cross Loading}

Factor loading, or Cross Loading are the value which describe that how much the variables are related to each factor in the model. Results shows that almost all items of all constructs are loaded in their own constructs. 


\begin{tabular}{lllll}
\hline & & & & \\
Items & Dominating & Job Satisfaction & Turnover Intention & Compromising \\
\hline Comp1 & 0.8462 & 0.4387 & 0.3537 & -0.0245 \\
Comp2 & 0.8914 & 0.3818 & 0.4138 & 0.0823 \\
Comp3 & 0.7425 & 0.2867 & 0.2044 & 0.0855 \\
Comp4 & 0.8299 & 0.4011 & 0.2561 & 0.1207 \\
Domi1 & 0.3958 & 0.6937 & 0.269 & 0.0518 \\
Domi2 & 0.2336 & 0.659 & 0.2382 & 0.1908 \\
Domi3 & 0.4637 & 0.7644 & 0.2889 & 0.2312 \\
Domi4 & 0.4638 & 0.7849 & 0.4773 & 0.2551 \\
Domi5 & 0.1089 & 0.6851 & 0.4936 & 0.0466 \\
JS1 & 0.3391 & 0.4359 & 0.709 & 0.0504 \\
JS2 & 0.1585 & 0.3029 & 0.6124 & 0.163 \\
JS3 & 0.1944 & 0.2486 & 0.6733 & -0.0033 \\
JS4 & 0.3497 & 0.3275 & 0.6915 & 0.052 \\
JS5 & 0.3273 & 0.4692 & 0.8376 & 0.0103 \\
JS6 & 0.2184 & 0.3755 & 0.6932 & -0.0069 \\
TI1 & 0.0535 & 0.1889 & 0.0292 & 0.9729 \\
TI2 & 0.1117 & 0.2515 & 0.0993 & 0.9688 \\
TI3 & -0.0866 & 0.0376 & -0.081 & 0.4585 \\
\hline
\end{tabular}

Table 4 AVE, COMPOSITE RELIABILITY, R-SQUARE, CRONBACH'S ALPHA

\begin{tabular}{llll} 
AVE & Composite Reliability & $R$ Square & Cronbach's Alpha \\
\hline Compromising & 0.6877 & 0.8977 & 0 \\
Dominating & 0.5171 & 0.842 & 0 \\
Job satisfaction & 0.5086 & 0.8553 & 0.3042 \\
Turnover intention & 0.6984 & 0.8643 & 0.0507 \\
\hline
\end{tabular}

The standard value of AVE value must be greater than 0.5 and Composite reliability must be greater than 0.7 for all constructs. The factor loadings, AVE, composite reliability, $R$ square value, and Cronbach's alpha and communality values are equal or more than standard value and has been given in Table. So, the AVE of each construct is greater than 0.5 and Composite Reliability of each construct is greater than 0.7. Consequently, it is confirmed that the items which are measured are fitted in one construct.

\section{Path Coefficient}

Table 5 PATH COEFFICIENT

\begin{tabular}{llll}
\hline & & & \\
& Beta & Standard Deviation & T Statistics \\
\hline Compromising $->$ job satisfaction & 0.262 & 0.1065 & 2.461 \\
Compromising $->$ turnover intention & -0.0836 & 0.1211 & 0.6904 \\
Dominating $->$ job satisfaction & 0.3046 & 0.1095 & 2.7823 \\
Dominating $->$ turnover intention & 0.3063 & 0.1095 & 2.7966 \\
\hline
\end{tabular}

It is said by Chin (1998) that by the process of bootstrapping we can drive the value of $t$ of all paths to determine either the hypotheses are accepted or rejected. So, $t$-value concluded the significance of relationship among all variables. 
The significance value of $t$-value is 1.96 having significance level of 0.05 as mentioned by Hair et al. (2006).

The results show that compromising style of conflict management positively related with job satisfaction of employees with path co efficient $0.262(t=2.461, p=0.05)$. So, the hypothesis compromising is related to job satisfaction is accepted.

The results show that compromising style of conflict management not related to turnover intention of employees at workplace with path co efficient $-0.0836(t=0.6904)$. So, the hypothesis compromising is related to turnover intention is rejected.

Likewise results indicates that Dominating style of conflict management negatively related with job satisfaction of employees with path co efficient $0.3046(t=2.7823, p=0.05)$. So, the hypothesis Dominating is related to job satisfaction is accepted.

Also results shows that Dominating style of conflict management positively related with turnover intention of employees with path co efficient $0.3063(t=2.7966, p=0.05)$. So, the hypothesis Dominating is related to job satisfaction is accepted.

\section{Structural Equation Modelling}

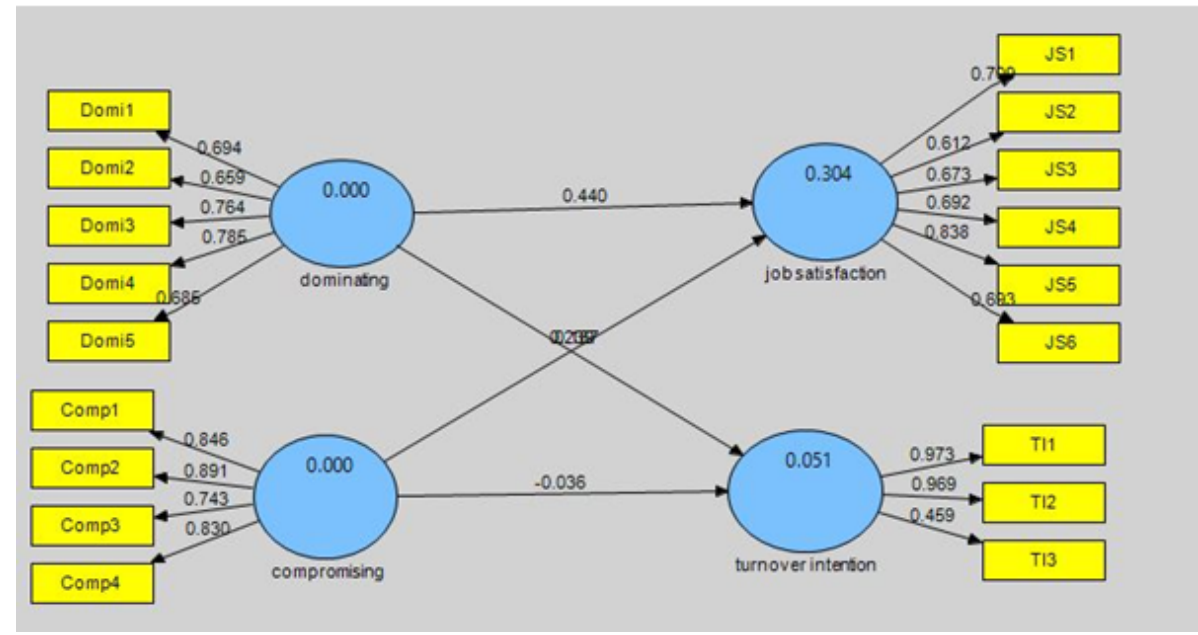

Figure 3 Structural Equation Modelling

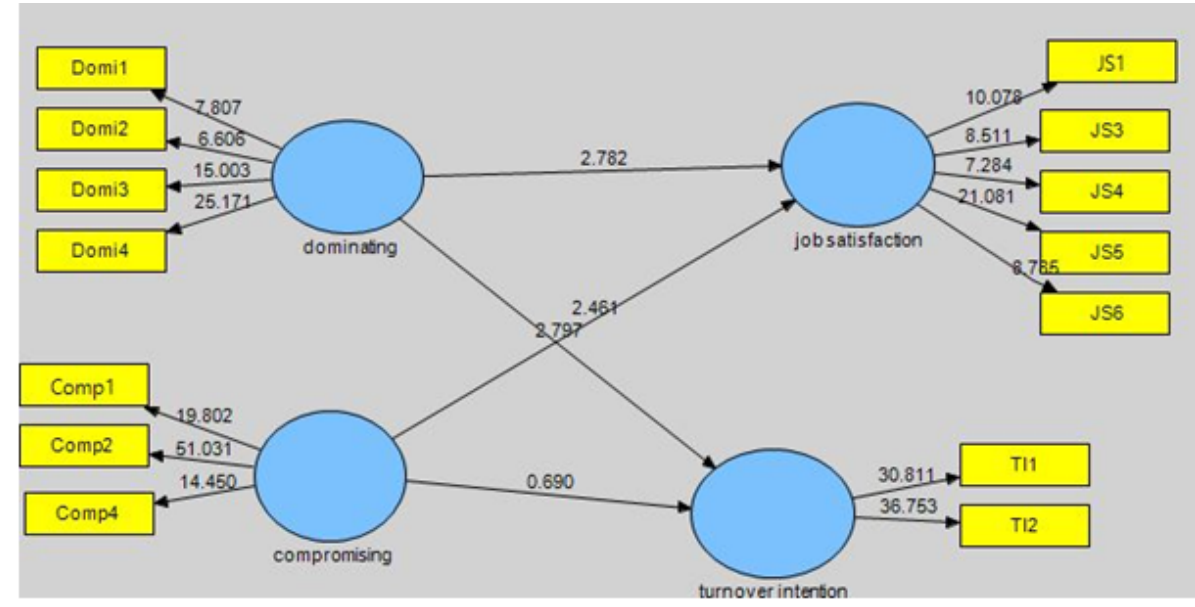

Figure 4 Structural Equation Modelling

\section{Contribution of study}

This paper contributes in two perspectives. In first it is concluded that positive conflict management positively related to positive work-related outcomes and second one is that negative conflict management styles including dominating is negatively related to positive work-related attitudes. But even strong evidences found in literature, one hypothesis the compromising conflict management style negatively related with turnover intention is not supported by 
results. This research provides a comprehensive detail about how conflict management styles effects employee's work attitudes and provide a in depth study about how supervisors/bosses make strategies that positively impacts employee's work attitudes.

\section{DISCUSSION}

As said by Choi (2013) that conflict management strategies at workplace like dominating, collaborating, and avoiding have different impact on employee job satisfaction. Whereas it was discussed by Rahim and Bonoma (1979) that evidences found in organizational conflict literature proposes that conflict at workplace is un avoidable, but it can be functional or dysfunctional for the organizations. This study concluded that if supervisor are compromising and obliging, employees are more satisfied as literature on organizational conflict also concluded that also shows that "integrating, compromising, and obliging styles" are positively linked with positive work attitude including job satisfaction G. R. Ferris and Kacmar (1992), Lawrence and Lorsch (1967), Likert (1967), Rahim and Bonoma (1979), (Korabik, Baril, \& Watson, 1993; Tutzauer \& Roloff, 1988; Wall \& Callister, 1995; Vigil, 2000). Likewise, it was also argued by shahani et al, 2017 that "Conflict can be major and detrimental element in perspective of employee satisfaction and job performance, if its existence is in excess amount, unnecessary, uncontrollable and unmanageable". Consequently, job satisfaction is major source of represents "work satisfaction, enthusiasm, and enjoyment", because it is work as most potential factor to determine work related outcomes like "increased organizational commitment and decreased turnover rate" (Brown \& Peterson, 1993; K. N. Wright, Saylor, Gilman, \& Camp, 1997; T. A. Wright \& Bonett, 2007). So, if there is dominating approach of bosses there will be decrease level of job satisfaction and increased level of turnover intention.it was also found in literature that dominating strategies of bosses or supervisor impact negatively on employee work related attitudes e.g., Pahayahay et al. (2017).

\section{CONCLUSION}

It is said by De and Van (2001) "employees may develop a shared tendency to approach and manage conflict, searching for solutions that are satisfactory to all team members (integrating), using authority or interpersonal influence (dominating), giving into wishes of the partners (yielding), trying to avoid disagreement or unpleasantness (avoiding) and proposing a "middle ground" solution (compromising)". Conflict is concluded as dysfunctional at workplace if is handled improperly conclusion is align with various studies including (Jehn \& Chatman, 2000; Sullivan \& Feltz, 2001; K. N. Wright et al., 1997) Likewise, it is also regarded as functional by many studies if it is efficiently handled.

According to Liu and Dong (2016) "Employee job satisfaction has been described as being among the most important variables in organizational studies due, in part, to its linkage with other important outcomes like organizational commitment, absenteeism, turnover, and work effort". Employees are likely to more be satisfied if they feel their bosses are compromising in nature.

\section{REFERENCES}

Adams, J. S. (1965). Inequity in social exchange. In L. Berekowitz (Ed.), Advances in experimental social psychology. New York, NY: Elsevier.

Alimba, C. (2008). The place of peace education in achieving the millenium development goals in Nigeria. International Journal of Educational Research and Administration, 5(1), 76-81.

Alper, S., Tjosvold, D., \& Law, K. S. (2000). Conflict management, efficacy, and performance in organizational teams. Personnel Psychology, 53(3), 625-642. doi:https://doi.org/10.1111/j.1744-6570.2000.tb00216.x

Bhalerao, S. (2016). Role of emotional intelligence in organizational conflict management. International Journal of Business and Administrative Studies, 2(2), 37-43. doi:https://doi.org/10.20469/ijbas.2.10003-2

Blake, R., \& Mouton, J. (1964). The managerial grid: The key to leadership excellence. Houston, TX: Gulf Publishing Co.

Brown, S. P., \& Peterson, R. A. (1993). Antecedents and consequences of salesperson job satisfaction: Meta-analysis and assessment of causal effects. Journal of Marketing Research, 30(1), 63-77. doi:https://doi.org/10.1177/ 002224379303000106

Cammann, C., Fichman, M., Jenkins, D., \& Klesh, J. (1979). The Michigan organizational assessment questionnaire (Unpublished master's thesis). University of Michigan, Ann Arbor, MI. 
Carpenter, S. L., \& Kennedy, W. J. (2001). Managing public disputes: A practical guide for government, business, and citizens' groups. New York, NY: Jossey-Bass.

Chin, W. W. (1998). The partial least squares approach to structural equation modeling. Modern Methods for Business Research, 295(2), 295-336. doi:https://doi.org/10.1007/978-3-319-71691-6_1

Choi, Y. (2013). The influence of conflict management culture on job satisfaction. Social Behavior and Personality: An International Journal, 41(4), 687-692. doi:https://doi.org/10.2224/sbp.2013.41.4.687

De, C. K., Dreu, \& Van, A. E., Vianen. (2001). Managing relationship conflict and the effectiveness of organizational teams. Journal of Organizational Behavior, 22(3), 309-328. doi:https://doi.org/10.1002/job.71

Dennis, G. L. (1998). Here today, gone tomorrow. Corrections Today, 60(3), 96-101.

Ferris, G., Russ, G., \& Fandt, P. (1989). Politics in organizations: Impression management in organizations. Newbury Park, CA: Sage Publishers.

Ferris, G. R., \& Kacmar, K. M. (1992). Perceptions of organizational politics. Journal of Management, 18(1), 93-116. doi:https://doi.org/10.1177/014920639201800107

Hair, J. F., Black, W. C., Babin, B. J., Anderson, R. E., Tatham, R. L., et al. (2006). Multivariate data analysis (vol. 6). Upper Saddle River, NJ: Pearson Prentice Hall.

Jehn, K. A., \& Chatman, J. A. (2000). The influence of proportional and perceptual conflict composition on team performance. International Journal of Conflict Management, 11(1), 56-73. doi:https://doi.org/10.1108/eb022835

Judge, T. A. (1994). Job satisfaction: How people feel about their jobs and how it affects their performance. Administrative Science Quarterly, 39(1), 186-199. doi:https://doi.org/10.2307/2393502

Kahn, R. L., Wolfe, D. M., Quinn, R., Snoek, J. D., \& Rosenthal, R. A. (1964). Organizational stress. New York, NY: Wiley.

Korabik, K., Baril, G. L., \& Watson, C. (1993). Managers' conflict management style and leadership effectiveness: The moderating effects of gender. Sex Roles, 29(5-6), 405-420. doi:https://doi.org/10.1007/bf00289432

Lawrence, P. R., \& Lorsch, J. W. (1967). Differentiation and integration in complex organizations. Administrative Science Quarterly, 12(1), 1-47. doi:https://doi.org/10.2307/2391211

Likert, R. (1967). The human organization: Its management and values. New York, NY: McGraw-Hill.

Liu, H., \& Dong, X. (2016). Influence of social relations on knowledge conflicts-an empirical study from Chinese universities. Journal of Administrative and Business Studies, 2(1), 8-18. doi:https://doi.org/10.20474/-jabs2.1.2

Macdonald, S., \& Maclntyre, P. (1997). The generic job satisfaction scale: Scale development and its correlates. Employee Assistance Quarterly, 13(2), 1-16. doi:https://doi.org/10.1300/j022v13n02_01

Mahdieh, O. (2015). Interaction between communication and organizational conflict and its relationship with performance. International Journal of Business and Administrative Studies, 1(2), 54-60. doi:https://doi.org/ 10.20469/ijbas.10002-2

Millikan, R. G. (1984). Language, thought, and other biological categories: New foundations for realism. Cambridge, MA: MIT Press.

Ozyurek, H., \& Uluturk, Y. (2016). Flexible budgeting under time-driven activity based cost as a tool in management accounting: Application in educational institution. Journal of Administrative and Business Studies, 2(2), 64-70. doi:https://doi.org/10.20474/jabs-2.2.2

Pahayahay, A. B., Asejo, N. R., Pangan, S. M., Dasig Jr., D. D., \& Panganiban Jr., A. S. (2017). A concurrent exploratory study on sectoral engagement model of an altruistic corporate social responsibility in bureau of jail management and penology. International Journal of Business and Economic Affairs, 2(2), 98-105. doi:https://doi.org/10.24088/ijbea-2017-22003

Papineau, D. (1987). For science in the social sciences. New York, NY: Springer.

Rahim, A., \& Bonoma, T. V. (1979). Managing organizational conflict: A model for diagnosis and intervention. Psychological Reports, 44(3), 1323-1344. doi:https://doi.org/10.2466/pr0.1979.44.3c.1323

Sullivan, P. J., \& Feltz, D. L. (2001). The relationship between intrateam conflict and cohesion within hockey teams. Small Group Research, 32(3), 342-355. doi:https://doi.org/10.1177/104649640103200304

Tett, R. P., \& Meyer, J. P. (1993). Job satisfaction, organizational commitment, turnover intention, and turnover: Path analyses based on meta-analytic findings. Personnel Psychology, 46(2), 259-293. doi:https://doi.org/10.1111/ j.1744-6570.1993.tb00874.x 
Thanasripanitchai, S. (2017). Daily activities management information system of Koglam-Sangaram Village: The self-sufficiency economy village model of Pid-Thong-Lang-Pha project. International Journal of Business and Economic Affairs, 2(1), 59-66. doi:https://doi.org/10.24088/ijbea-2017-21008

Thomas, C. (1976). The manawaka world of margaret laurence. Toronto, Canada: McClelland and Stewart.

Tjosvold, D. (2008). The conflict-positive organization: It depends upon us. Journal of Organizational Behavior, 29(1), 19-28. doi:https://doi.org/10.1002/job.473

Tutzauer, F., \& Roloff, M. E. (1988). Communication processes leading to integrative agreements: Three paths to joint benefits. Communication Research, 15(4), 360-380. doi:https://doi.org/10.1177/009365088015004002

Van, E., De Vliert, Euwema, M. C., \& Huismans, S. E. (1995). Managing conflict with a subordinate or a superior: Effectiveness of conglomerated behavior. Journal of Applied Psychology, 80(2), 271-279. doi:https://doi.org/ $10.1037 / / 0021-9010.80 .2 .271$

Vigil, K. D. (2000). Team conflict, integrative conflict-management strategies, and team effectiveness: A field study (Unpublished master's thesis). University of Michiga, Ann Arbor, MI.

Wall, J. A., Jr, \& Callister, R. R. (1995). Conflict and its management. Journal of Management, 21(3), 515-558. doi:https://doi.org/10.1177/014920639502100306

Wright, K. N., Saylor, W. G., Gilman, E., \& Camp, S. (1997). Job control and occupational outcomes among prison workers. Justice Quarterly, 14(3), 525-546. doi:https://doi.org/10.1080/07418829700093461

Wright, T. A., \& Bonett, D. G. (2007). Job satisfaction and psychological well-being as nonadditive predictors of workplace turnover. Journal of Management, 33(2), 141-160. doi:https://doi.org/10.1177/0149206306297582 